\title{
Peranan Manajemen Sumber Daya Manusia Terhadap Peningkatan Produktivitas Kerja
}

\author{
Daeng Pabalik $^{1 *}$ Hermanto Suaib $^{2}$, Nur Helmi ${ }^{3}$, Nanik Purwanti ${ }^{4}$ \\ ${ }^{1,2,3,4}$ Fakultas Ilmu Sosial dan Ilmu Politik, Universitas Muhammadiyah Sorong \\ email: daengpabalik@um-sorong.ac.id
}

\begin{abstract}
ABSTRAK
Tujuan dari penelitian ini adalah : 1) Untuk mengetahui penerapan Manajemen Sumber Daya Manusia (MSDM) dalam meningkatkan produktivitas kerja Medical Representative PT. Otto Pharmaceutical Industries cabang Sorong. 2) Untuk mengetahui nilai-nilai MSDM yang berpengaruh terhadap produktivitas kerja Medical Representative pada PT. Otto Pharmaceutical Industries cabang Sorong. 3) Untuk mengetahui kendalakendala apa saja yang dihadapi dalam penerapan Manajemen Sumber Daya Manusia terhadap peningkatan produktivitas kerja Medical Representative pada PT. Otto Pharmaceutical Industries cabang Sorong. Penelitian ini dilakukan di Kota Sorong, sedangkan objek penelitian adalah pihak yang diteliti, yaitu seluruh karyawan pada PT. Otto Pharmaceutical Industries cabang Sorong. Metode pengumpulan data menggunakan wawancara,dokumentasi, dan observasi. Jenis dan sumber data yaitu data primer dan data sekunder. Hasil penelitian menunjukan bahwa permasalahan yang dihadapi oleh para pimpinan adalah bagaimana dapat meningkatkan produktivitas kerja karyawannya sehingga dapat mendukung keberhasilan pencapaian tujuan perusahaan. Untuk itu pengelolaan sumber daya manusia sangat erat kaitannya dengan pencapaian tujuan tersebut. Karena semakin baik pengelolaan sumber daya manusia (tenaga kerja) maka semakin baik pula pengelolaan sumber daya yang lain, dan sebaliknya semakin buruk pengelolaan sumber daya manusia maka hal itu akan berakibat pengelolaan sumber daya yang lain akan semakin buruk.
\end{abstract}

Kata kunci : Manajemen Sumber Daya Manusia, Produktifitas kerja, Medical Representative

\begin{abstract}
The purpose of this study are: 1) To find out the application of Human Resource Management (HRM) in increasing the work productivity of Medical Representative of PT. Otto Pharmaceutical Industries Sorong branch. 2) To find out the HRM values that affect the work productivity of Medical Representatives at PT. Otto Pharmaceutical Industries Sorong branch. 3) To find out what obstacles are encountered in the application of Human Resources Management to increase work productivity of Medical Representative at PT. Otto Pharmaceutical Industries Sorong branch. This research was conducted in the city of Sorong, while the object of research was the party studied, namely all employees at PT. Otto Pharmaceutical Industries Sorong branch. Data collection methods using interviews, documentation, and observation. Types and sources of data are primary data and secondary data. The results showed that the problem faced by the leaders was how to increase the work productivity of their employees so that they could support the successful achievement of company goals. For this reason, human resource management is very closely related to the achievement of these goals. Because the better the management of human resources (labor), the better the management of other resources, and vice versa the worse the management of human resources, it will result in the management of other resources that will be worse.
\end{abstract}

Keywords : Human Resource Management, Work Productivity, Medical Representative

\section{PENDAHULUAN}

Salah satu permasalahan yang dihadapi oleh para pimpinan adalah bagaimana dapat meningkatkan produktivitas kerja karyawannya sehingga dapat mendukung keberhasilan pencapaian tujuan. Pengelolaan sumber daya manusia sangat erat kaitannya dengan energi yaitu 
bahan baku (material), modal (money), mesin (machines), serta energi (energi) dalam organisasi tersebut. Semakin baik pengelolaan sumber daya manusia (tenaga kerja) maka semakin baik pula pengelolaan sumber daya yang lain, dan sebaliknya semakin buruk pengelolaan sumber daya manusia maka hal itu akan berakibat pengelolaan sumber daya yang lain akan semakin buruk.

Manajemen Sumber Daya Manusia merupakan investasi yang sangat penting bagi suatu organisasi, karena sekalipun proses organisasi sudah didukung oleh peralatan teknologi yang canggih, tetap saja standar kinerja organisasi akan tetap tergantung kepada bagaimana sumber daya manusia yang ada mampu mengelola dan memanfaatkan semua potensi yang ada dalam organisasi tersebut.

Namun hingga saat ini masih banyak organisasi yang tidak menyadari betapa berharganya sumber daya manusia untuk kelangsungan hidup organisasi. Mogok kerja, absensi, dan perputaran tenaga kerja tinggi, produktivitas yang merosot, daya saing perusahaan yang rendah dan profesionalisme kerja tidak memadai adalah beberapa fenomena yang menandai adanya permasalahan dalam pengelolaan sumber daya manusia.

\section{PT. Otto Pharmaceutical}

Industries merupakan perusahaan manufaktur farmasi yang memproduksi berbagai obat-obatan berkualitas dengan tujuan untuk melayani Rakyat Indonesia. PT. Otto Pharmaceutical Industries didirikan pada 8 April 1963 di Bandung, Jawa Barat. Pada tahun 1981, dalam mengembangkan perusahaan tersebut sangat ditekankan pada pengembangan sumber daya manusia yang handal untuk meningkatkan serta mempertahankan penjualan dan pangsa pasar. Untuk menjadi salah satu perusahaan farmasi terkemuka di Indonesia, PT. Otto mulai memperluas penjualan hingga ke wilayah timur yang diantaranya telah membuka cabang di Kota Sorong Papua Barat.

Untuk itu tujuan dari penelitian ini adalah : 1) Untuk mengetahui penerapan Manajemen Sumber Daya Manusia (MSDM) dalam meningkatkan produktivitas kerja Medical Representative PT. Otto Pharmaceutical Industries cabang Sorong. 2) Untuk mengetahui nilainilai MSDM yang berpengaruh terhadap produktivitas kerja Medical Representative pada PT. Otto Pharmaceutical Industries cabang Sorong. 3) Untuk mengetahui kendala-kendala apa saja yang dihadapi dalam penerapan Manajemen Sumber Daya Manusia terhadap peningkatan produktivitas kerja Medical Representative pada PT. Otto Pharmaceutical Industries cabang Sorong. 


\section{METODE}

Penelitian ini bersifat kualitatif deskriptif yatitu suatu metode analisis data yang menentukan, menafsirkan, serta mengklasifikasikan data-data atau informasi tentang Peranan Manajemen Sumber Daya Manusia terhadap peningkatan produktivitas kerja Medical Representative pada PT. Otto
Pharmaceutical Industries cabang Sorong. Penelitian ini dilakukan di Kota Sorong, sedangkan objek penelitian adalah pihak yang diteliti, yaitu seluruh karyawan pada PT. Otto Pharmaceutical Industries cabang Sorong. Metode pengumpulan data menggunakan wawancara, dokumentasi, dan observasi. Jenis dan sumber data yaitu data primer dan data sekunder.

\section{HASIL DAN PEMBAHASAN}

\section{Pengembangan Sumber Daya Manusia}

Tabel 1. Tabulasi Jawaban Responden Mengenai Frekwensi Diklat

\begin{tabular}{cccc}
\hline No & Keterangan & Frekwensi & Presentase \\
\hline 1 & Pernah & 4 & 66,67 \\
2 & Tidak Pernah & 2 & 33,33 \\
& Jumlah & $\mathbf{6}$ & $\mathbf{1 0 0 , 0}$ \\
\hline
\end{tabular}

Sumber: Kusioner Penelitian (2015)

Berdasarkan tabel 1 dapat diketahui mengikuti diklat sebanyak 2 orang bahwa Frekwensi responden pernah (33,33\%).

mengikuti diklat sebanyak 4 orang $(66,67 \%)$ dan responden yang tidak pernah

Tabel 2. Tabulasi Jawaban Responden Mengenai Peningkatan Pengetahuan, Kemampuan Dan Sikap Setelah Mengikuti Diklat

\begin{tabular}{cccc}
\hline No & Keterangan & Frekwensi & Presentase \\
\hline 1 & Meningkat & 4 & 66,67 \\
2 & Tidak Meningkat & 2 & 33,33 \\
& Jumlah & $\mathbf{6}$ & $\mathbf{1 0 0 , 0}$ \\
\hline
\end{tabular}

Sumber: Kusioner Penelitian (2015)

Berdasarkan tabel 2 dapat diketahui bahwa terjadi peningkatan pengetahuan, kemampuan dan sikap setelah mengikuti diklat yaitu 4 orang responden mengatakan meningkat $(66,67 \%)$ dan 2 orang mengatakan tidak meningkat $(33,33 \%)$ karena mereka belum pernah mengikuti diklat. 
Tabel 3. Tabulasi Jawaban Responden Mengenai Apakah Materi Diklat Yang Diberikan Sesuai Dengan Pekerjaan Yang Dijalankan Saat Ini

\begin{tabular}{cccc}
\hline No & Keterangan & Frekwensi & Presentase \\
\hline 1 & Sesuai & 4 & 66,67 \\
2 & Tidak Sesuai & 2 & 33,33 \\
& Jumlah & $\mathbf{6}$ & $\mathbf{1 0 0 , 0}$ \\
\hline
\end{tabular}

Sumber : Kusioner Penelitian (2015)

Berdasarkan tabel 3 bahwa materi diklat umumnya telah sesuai dengan kebutuhan perusahaan tentang permasalahan yang dihadapi, sebanyak 4 orang responden mengatakan sesuai $(66,67 \%)$ dan 2 orang responden menjawab tidak sesuai $(33,33 \%)$.

\section{Pengembangan Diri}

Tabel 4. Tabulasi Jawaban Responden Mengenai Usaha Mengembangkan Diri Sendiri Dengan Belajar Secara Mandiri Berupa Membaca Buku, Referensi, Menonton Acara Pendidikan Dan Pelatihan Melalui Televisi.

\begin{tabular}{cccc}
\hline No & Keterangan & Frekwensi & Presentase \\
\hline 1 & Ya Selalu Berusaha & 0 & 0 \\
2 & Tidak Pernah & 6 & 100 \\
& Jumlah & $\mathbf{6}$ & $\mathbf{1 0 0}$ \\
\hline
\end{tabular}

Sumber: Kusioner Penelitian (2015)

Berdasarkan tabel 4 bahwa referensi, menonton acara pendidikan dan responden tidak pernah berusaha pelatihan melalui televisi, yaitu 6 orang mengembangkan diri sendiri dengan belajar mengatakan tidak pernah (100\%). secara mandiri berupa membaca buku,

Tabel 5 Tabulasi Jawaban Responden Karyawan Mengenai Perusahaan Memberikan

Kesempatan Untuk Pengembangkan Diri Sendiri Melalui Suatu Organisasi Berupa Acara Seminar, Lokakarya, Pameran, Juga Studi Banding

\begin{tabular}{cccc}
\hline No & Keterangan & Frekwensi & Presentase \\
\hline 1 & Pernah & 0 & 0 \\
2 & Tidak Pernah & 6 & 100 \\
& Jumlah & $\mathbf{6}$ & $\mathbf{1 0 0}$ \\
\hline
\end{tabular}

Sumber: Kusioner Penelitian (2015)

Berdasarkan tabel diatas bahwa mengembangkan diri sendiri melalui suatu manajemen tidak pernah memberikan organisasi berupa acara seminar, lokakarya, kesempatan kepada karyawannya untuk pameran, juga studi banding. 
Tabel 6. Tabulasi Jawaban Responden Mengenai Apakah Pengaruh Pengembangan Diri Dengan Belajar Mandiri Maupun Belajar Melalui Suatu Organisasi Dapat Mempengaruhi Sikap Dan Kinerja Karyawan.

\begin{tabular}{cccc}
\hline No & Keterangan & Frekwensi & Presentase \\
\hline 1 & Ya Sangat Mempengaruhi & 6 & 100 \\
2 & Tidak Mempengaruhi & 0 & 0 \\
& Jumlah & $\mathbf{6}$ & $\mathbf{1 0 0}$ \\
\hline
\end{tabular}

Sumber: Kusioner Penelitian (2015)

Berdasarkan tabel diatas dapat dapat mempengaruhi sikap dan kinerja dilihat bahwa responden mengetahui bahwa Karyawan, dari 6 orang responden pengembangan diri dengan belajar mandiri semuanya menjawab ya sangat maupun belajar melalui suatu organisasi mempengaruhi (100\%).

\section{Promosi}

Tabel 7. Tabulasi Jawaban Responden Mengenai Promosi Jabatan Di Perusahaan

\begin{tabular}{cccc}
\hline No & Keterangan & Frekwensi & Presentase \\
\hline 1 & Pernah & 0 & 0 \\
2 & Belum Pernah & 6 & 100 \\
& Jumlah & $\mathbf{6}$ & $\mathbf{1 0 0}$ \\
\hline
\end{tabular}

Sumber: Kusioner Penelitian (2015)

Berdasarkan tabel 7 dapat dilihat responden yang mana semuanya menjawab bahwa mayoritas dari responden belum belum pernah $(100 \%)$.

pernah mendapatkan promosi jabatan dari perusahaan, ini terlihat dari jawaban 6 orang

Tabel 8 Tabulasi Jawaban Responden Mengenai Apakah Promosi Diberikan Berdasarkan Kinerja.

\begin{tabular}{cccc}
\hline No & Keterangan & Frekwensi & Presentase \\
\hline 1 & Ya & 6 & 100 \\
2 & Tidak & 0 & 0 \\
& Jumlah & $\mathbf{6}$ & $\mathbf{1 0 0}$ \\
\hline
\end{tabular}

Sumber: Kusioner Penelitian (2015)

Berdasarkan tabel diatas dapat Jabatan, dari jawaban responden sebanyak 6 dilihat bahwa responden mengetahui bahwa orang semuanya mengatakan ya (100\%).

Promosi diberikan berdasarkan kinerja 


\section{Kualitas}

Tabel 9. Tabulasi Jawaban Responden Mengenai Apakah Merasa Senang Pada Hasil Kerja

\begin{tabular}{cccc}
\hline No & Keterangan & Frekwensi & Presentase \\
\hline 1 & Ya Senang & 6 & 100 \\
2 & Tidak Senang & 0 & 0 \\
& Jumlah & $\mathbf{6}$ & $\mathbf{1 0 0}$
\end{tabular}

Sumber: Kusioner Penelitian (2015)

Berdasarkan tabel diatas dapat senang (100\%) dengan hasil pekerjaan yang dilihat bahwa semua responden mengatakan dilaksanakan.

Tabel 10. Tabulasi Jawaban Responden Mengenai Apakah Terdapat Kendala Dalam Melaksanakan Pekerjaan

\begin{tabular}{cccc}
\hline No & Keterangan & Frekwensi & Presentase \\
\hline 1 & Sering Sekali & 5 & 83,33 \\
2 & Tidak Pernah & 1 & 16,67 \\
& Jumlah & $\mathbf{6}$ & $\mathbf{1 0 0}$ \\
\hline
\end{tabular}

Sumber: Kusioner Penelitian (2015)

Berdasarkan tabel diatas dapat orang mengatakan sering sekali $(83,33 \%)$ dilihat bahwa kendala kerja sering dialami dan 1 orang mengatakan tidak pernah oleh responden, dari 6 orang responden $5 \quad(16,67 \%)$

Tabel 11. Tabulasi Jawaban Responden Mengenai Kemampuan Melaksanakan Tanggung Jawab Yang Lebih Besar

\begin{tabular}{cccc}
\hline No & Keterangan & Frekwensi & Presentase \\
\hline 1 & Mampu & 1 & 16,67 \\
2 & Tidak mampu & 5 & 83,33 \\
& Jumlah & $\mathbf{6}$ & $\mathbf{1 0 0}$
\end{tabular}

Sumber: Kusioner Penelitian (2015)

Berdasarkan tabel diatas dapat besar, dari 6 orang responden hanya 1 orang dilihat bahwa dalam keadaan sekarang yang mengatakan mampu $(16,67 \%)$ dan 5 responden belum cukup mampu untuk orang mengatakan kurang mampu melaksanakan tanggung jawab yang lebih (83,33\%).

\section{Ketepatan Waktu Kerja}

Tabel 12. Tabulasi Jawaban Responden Mengenai Apakah Ada Penundaan Waktu Dalam Menyelesaikan Tugas

\begin{tabular}{cccc}
\hline No & Keterangan & Frekwensi & Presentase \\
\hline 1 & Pernah & 4 & 66,67 \\
2 & Tidak pernah & 2 & 33,33 \\
\hline
\end{tabular}

104 Peranan manajemen sumber daya manusia.......... 


\begin{tabular}{ccc}
\hline Jumlah & $\mathbf{6}$ & $\mathbf{1 0 0}$ \\
\hline Sumber: Kusioner Penelitian $(2015)$
\end{tabular}

Sumber: Kusioner Penelitian (2015)

Berdasarkan tabel diatas dapat orang mengatakan pernah $(66,67 \%)$ dan 2 dilihat bahwa penundaan pekerjaan masih orang mengatakan tidak pernah $(33,33 \%)$ sering terjadi pada diri karyawan hal ini dilihat dari 6 orang responden terdapat 4

Tabel 13. Tabulasi Jawaban Responden Mengenai Kepatuhan Peraturan Jam Kerja

\begin{tabular}{cccc}
\hline No & Keterangan & Frekwensi & Presentase \\
\hline 1 & Ya Selalu Patuh & 6 & 100 \\
2 & Kurang Patuh & 0 & 0 \\
& Jumlah & $\mathbf{6}$ & $\mathbf{1 0 0}$ \\
\hline
\end{tabular}

Sumber: Kusioner Penelitian (2015)

Berdasarkan tabel diatas dapat manajemen, dari 6 orang responden $100 \%$ dilihat responden selalu patuh dengan jam menjawan ya selalu patuh. kerja yang telah ditetapkan oleh pihak

\section{Dampak Interpersonal}

Tabel 14. Tabulasi Jawaban Responden Mengenai Rasa Bangga Bekerja Di Perusahaan Ini

\begin{tabular}{cccc}
\hline No & Keterangan & Frekwensi & Presentase \\
\hline 1 & Ya bangga & 6 & 100 \\
2 & Kurang bangga & 0 & 0 \\
& Jumlah & $\mathbf{6}$ & $\mathbf{1 0 0}$ \\
\hline
\end{tabular}

Sumber: Kusioner Penelitian (2015)

Berdasarkan tabel diatas dapat dilihat dari jawaban 6 orang responden dilihat bahwa responden selalu merasa (100\%) yang menjawab ya bangga. bangga bekerja di perusahaan, ini dapat

Tabel 15. Tabulasi Jawaban Responden Mengenai Menjaga Hubungan Personal

\begin{tabular}{cccc}
\hline No & Keterangan & Frekwensi & Presentase \\
\hline 1 & Ya Selalu Menjaga & 6 & 100 \\
2 & Kurang Menjaga & 0 & 0 \\
& Jumlah & $\mathbf{6}$ & $\mathbf{1 0 0}$ \\
\hline
\end{tabular}

Sumber: Kusioner Penelitian (2015)

Berdasarkan tabel diatas dapat selalu menjaga hubungan baik, hal ini dilihat bahwa hubungan personal yang dilihat dari jawaban 6 orang responden terbangun diatara rekan kerja maupun atasan $\quad(100 \%)$ menjawab ya selalu menjaga. 


\section{Pembahasan}

Berdasarkan hasil kusioner menunjukan bahwa peranan Manajemen Sumber Daya Manusia pada PT. Otto Pharmaceutical Industries cabang Sorong masih sangat rendah hal ini dilihat dari beberapa indikator :

\section{Indikator Pendidikan dan Pelatihan}

Partisipasi karyawan PT. Otto Pharmaceutical Industries cabang Sorong dalam mengikuti diklat belum maksimal yaitu dengan frekwensi pernah mengikuti diklat sebanyak 4 orang $(66,67 \%)$ dan yang belum pernah mengikuti diklat sebanyak 2 orang $(33,33 \%)$, sementara jenjang-jenjang diklat yang diikuti oleh seorang karyawan hanya sebatas tentang diklat pengenalan tentang Medical Representative dan untuk diklat yang lebih tinggi hanya berlaku bagi pimpinan pada level Area Manager dan Regional Manager.

\section{Indikator Kegiatan Non Diklat}

Kegiatan non diklat adalah kegiatan pengembangan diri diluar kegiatan formal yang dilakukan oleh perusahaan. Kegiatan ini dapat ditempuh dengan cara belajar sendiri, secara mandiri maupun melalui suatu instansi di luar organisasi, menunjukan bahwa responden tidak pernah mengembangkan diri sendiri baik berupa membaca buku, referensi maupun menonton acara pendidikan dan pelatihan melalui televisi. Hal ini menunjukan bahwa karyawan belum memiliki kesadaran sendiri untuk mencari dan mengembangkan dirinya. Kegiatan non diklat ini sangat penting untuk menambah pengalaman belajar kepada karyawan.

\section{Indikator Promosi}

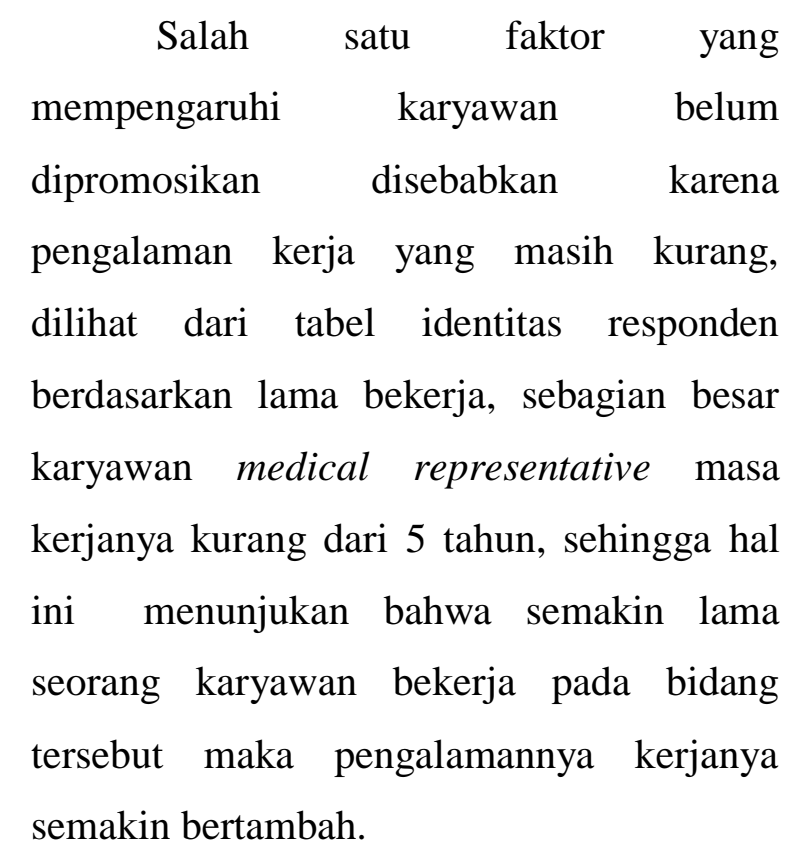

Indikator Kualitas

Pada tabel terlihat bahwa hasil pekerjaan yang ditunjukan oleh karyawan medical representative sudah cukup maksimal, karena mereka selalu merasa senang pada hasil pekerjaan mereka. Ketika hasil kerja yang telah dicapai tersebut baik maka pada akhirnya akan mendatangkan rasa puas dalam diri seorang pegawai/karyawan, bahkan lebih giat untuk mendapatkan hasil yang lebih maksimal lagi. Sebaliknya jika karyawan hanya 
merasa sedikit senang dengan kualitas kerjanya maka akan membawa pengaruh buruk pada tugas selanjutnya bahkan akan mempengaruhi tingkat pendapatan perusahaan.

\section{Indikator Ketepatan Waktu Kerja}

Pada tabel responden karyawan medical representative pernah menunda pekerjaan $(66,67 \%)$ dan tidak pernah menunda pekerjaan $(33,33 \%)$ akibatnya waktu menyelesaikan suatu pekerjaan menjadi bertambah. Maka dapat dipastikan lembur menjadi pilihan sebagai jalan keluarnya. Pemakaian waktu dengan baik tanpa menunda menyelesaikan sebuah pekerjaan adalah bakti pada perusahaan.

\section{Aplikasi Nilai-Nilai Manajemen Sumber} Daya Manusia Terhadap Peningkatan Produktivitas Kerja Medical

\section{Representative}

Pengembangan sumber daya manusia (PSDM) dalam Perusahaan pada dasarnya suatu bentuk usaha untuk meningkatkan daya tahan saing organisasi terhadap ancaman lingkungan eksternal dan suatu usaha untuk meningkatkan daya inovatif untuk menciptakan peluang. Dengan demikian PSDM dalam perusahaan merupakan bentuk usaha pengembangan yang bersifat integral baik yang menyangkut SDM sebagai individu dan sebagai sistem maupun organisasi sebagai wadah SDM untuk memenuhi kebutuhannya.

\section{Pendidikan dan Pelatihan}

Hal ini bertujuan untuk mengembangkan individu dalam bentuk peningkatan ketrampilan, pengetahuan dan sikap,. Sedangkan Pendidikan bertujuan meningkatkan kemampuan kerjanya dalam arti luas sifat pengembangan ini umumnya bersifat formal dan sering berkait dengan karir.

\section{Program Pembinaan}

Bertujuan mengatur dan membina manusia sebagai sub sistem organisasi/perusahaan melalui programprogram perencana dan penilaian seperti, yang tertuang pada beberapa indikator diatas antara lain: Indikator Kegiatan Non Diklat, Indikator Promosi, Indikator Kualitas, dan Indikator Ketepatan Waktu Kerja.

\section{Recruitmen}

Mendapat SDM sesuai klasifikasi kebutuhan organisasi dan sebagai salah satu alat organisasi dalam pembaharuan dan pengembangan, karena melalui hasil wawancara dengan pihak managemen, karyawan pada PT. OTTO sering terjadi pergantian atau terjadi pengunduran diri karyawan, maka hal ini menjadi salah satu faktor penyebab menurunnya produktifitas perusahaan. 


\section{Perubahan Sistem}

Bertujuan untuk menyesuaikan sistem dan prosedur perusahaan sebagai jawaban untuk mengantisipasi ancaman dan peluang faktor eksternal. Pengembangan organisasi bertujuan untuk menjembatani perubahan-perubahan dan pengembangan baik dari sisi internal maupun eksternal.

Terdapat beberapa kendala yang dihadapi oleh PT. Otto cabang Sorong antara lain : a) Ketersediaan tenaga kerja pada bidang yang dicari. Jika bidang yang dicari merupakan bidang yang tergolong langka, maka perusahaan akan lebih sulit dalam memenuhi kebutuhan karyawannya. Misalnya, tenaga kerja yang di cari adalah bidang farmasi, Managemen Pemasaran dll. b) Keterbatasan tingkat pendidikan dan keterampilan para karyawan yang mempengaruhi produktifitas. c) Prestasi karyawan lama cenderung turun, karena tidak ada kesempatan untuk promosi. d)

\section{DAFTAR PUSTAKA}

Almasdi, Yunus Suit 2006, Aspek Sikap Mental Dalam Manajemen Sumber Daya Manusia Indonesia, Ghalia Indonesia, Jakarta

Ambar T. Sulistiani dan Rosidah 2003, dalam bukunya yang berjudul
Munculya para kompetitor di bidang yang sama, dengan bermunculan produk-produk farmasi yang mengakibatkan pemilihan produk oleh para dokter dan apotik berbalik arah. e) Sering terjadinya keterlambatan dalam pengiriman produk dari pabrik mengakibatkan para dokter sering beralih ke produk perusahaan lain.

\section{SIMPULAN}

Salah satu permasalahan yang dihadapi oleh para pimpinan adalah bagaimana dapat meningkatkan produktivitas kerja karyawannya sehingga dapat mendukung keberhasilan pencapaian tujuan perusahaan. Untuk itu pengelolaan sumber daya manusia sangat erat kaitannya dengan pencapaian tujuan tersebut. Karena semakin baik pengelolaan sumber daya manusia (tenaga kerja) maka semakin baik pula pengelolaan sumber daya yang lain, dan sebaliknya semakin buruk pengelolaan sumber daya manusia maka hal itu akan berakibat pengelolaan sumber daya yang lain akan semakin buruk.

Manajemen Sumber Daya Manusia. Penerbit : Bumi Aksara, Jakarta

Basuki, Sulistiyo, 2010, Metode Penelitian, Penaku : Jakarta

Basir Barthos, Drs, 2012, Manajemen Sumber Daya Manusia Pendekatan Makro, Cetakan kesembilan, Penerbit PT. Bumi Aksara, Jakarta 


\section{Noken Volome 2(2) Halaman : 99-109| 2019}

Chris Rowley, Keith Jackson, 2012, Manajemen Sumber Daya Manusia : The Key Concepts, PT. Raja Grafindo Persada, Jakarta

Edy Sutrisno, 2009, Manajemen Sumber

Daya Manusia, Perdana Media Group, Jakarta

H. Afifuddin, Prof., SE, MM, 2014, Manajemen Personalia, Cetakan pertama, Penerbit CV. Pustaka Setia, Bandung

Hasan, Iqbal, M, 2002, Pokok-Pokok Materi Statistik I (Statistik Deskriptif), Edisi kedua, Cetakan Pertama, Penerbit : Bumi Aksara, Jakarta

Hasibuan, H. Malayu, S.P, 2001, Manajemen Sumber Daya Manusia, Edisi Revisi, Cetakan ketiga, Penerbit : Bumi Aksara, Jakarta

Komaruddin, Sastradipoera, 2006, Pengembangan dan Pelatihan, Kappa-Sigma, Bandung
Komarudin, 1994, Ensiklopedia Manajemen, Bumi Aksara, Jakarta

Marihot Tua Efendi Hariandja, Drs., M.Si, 2009, Manajemen Sumber Daya Manusia, Cetakan kelima, Penerbit PT. Gramedia, Jakarta

Siti Al Fajar dan Tri Heru, 2010, Manajemen Sumber Daya Manusia, STIE Management YKPN, Yogyakarta

Suryadi Prawirosentono, Dewi Primasari, 2014, Manajemen Strategik dan Pengambilan Keputusan Korporasi, Cetakan Pertama, Penerbit PT. Bumi Aksara, Jakarta

Soekanto, 1990, Sosiologi Suatu Pengantar, PT. Raja Grafindo Persada, Jakarta

W. J. S Poerwadarminta, 1985, Kamus Bahasa Indonesia, PN. Balai Pustaka, Jakarta 